\title{
ANALISIS KEMAMPUAN PEMECAHAN MASALAH MATEMATIKA BERDASARKAN TAKSONOMI STRUCTURE OF OBSERVED LEARNING OUTCOMES (SOLO)
}

\author{
Halimah $^{1)}$ \\ Zainuddin Untu ${ }^{2)}$ \\ Suriaty $^{3)}$ \\ ${ }^{1), 2), 3)}$ Program Studi Pendidikan Matematika, Universitas Mulawarman \\ Email: ${ }^{2)}$ zainuddin.untu@fkip.unmul.ac.id
}

\begin{abstract}
ABSTRAK
Jenis penelitian ini adalah deskriptif kualitatif dengan tujuan untuk mengetahui dan mengklasifikasikan kemampuan pemecahan masalah matematika siswa berdasarkan Taksonomi Structure of Observed Learning Outcomes (SOLO) pada materi barisan dan deret di MA Negeri 1 Samarinda tahun ajaran 2019/2020. Subjek penelitian adalah siswa kelas XI IPA di MA Negeri 1 Samarinda yang berjumlah 66 orang. Objek penelitian adalah kemampuan pemecahan masalah siswa pada materi barisan dan deret berdasarkan Taksonomi SOLO. Instrumen yang digunakan dalam penelitian ini adalah soal tes pemecahan masalah dan pedoman wawancara. Hasil penelitian menunjukkan bahwa, dari 66 subjek diperoleh 5 siswa dengan kategori kemampuan prastruktural, 15 siswa dengan kategori kemampuan unistruktural, 29 siswa dengan kategori kemampuan multistruktural, 14 siswa dengan kategori kemampuan relasional, dan 3 siswa dengan kategori kemampuan kategori abstrak yang diperluas. Dengan demikian disimpulkan bahwa, berdasarkan klasifikasi Taksonomi SOLO, kemampuan pemecahan masalah siswa kelas XI IPA di Madrasah Aliyah Negeri 1 Samarinda sebagian besar berada pada kategori kemampuan multistruktural yang berarti memenuhi indikator taksonomi SOLO pada tingkatan unistruktural dan tingkatan multistruktural.
\end{abstract}

Kata kunci: Kemampuan, Pemecahan Masalah Matematika, Taksonomi SOLO

\begin{abstract}
The type of this research is descriptive qualitative with the aim to study and classify problem solving problems of class XI IPA students based on the Observational Structure of Observed Learning Outcomes (SOLO) on marching and series material in MA Negeri 1 Samarinda 2019/2020 school year. The research subjects were students of class XI IPA in MA Negeri 1 Samarinda, which gathered 66 people. The object of research is the solving of students' problems on sequential and series material based on SOLO Taxonomy. The instrument used in this study was a matter of problem solving tests and interview guidelines. The results showed that, from the overall research subjects obtained 5 students with pre-structural taxonomic category abilities, 15 students with unistructural taxonomic category abilities, 29 students with multistructural
\end{abstract}


taxonomic category abilities, 14 students with relational taxonomic category abilities and 3 students with abstract abstract taxonomy abilities expanded. Thus it was concluded that, the problem solving ability of class XI IPA students in MA Negeri 1 Samarinda was still mostly in the multistructural taxonomy category, which meant fulfilling SOLO taxonomic indicators at the unistructural and multistructural levels.

Keywords: Ability, Mathematics Problem Solving, SOLO Taxonomy

\section{PENDAHULUAN}

Matematika merupakan ilmu universal yang memiliki peranan penting dalam berbagai disiplin ilmu untuk memajukan daya fikir manusia. Pentingnya belajar matematika tidak hanya dipelajari di dalam kelas, namun belajar matematika erat kaitannya dengan kehidupan sehari-hari. Dalam Permendikbud Nomor 58 Tahun 2014 dijelaskan bahwa matematika merupakan ilmu universal yang berguna bagi kehidupan manusia dan juga mendasari perkembangan teknologi modern, serta mempunyai peran penting dalam berbagai disiplin untuk memajukan daya pikir manusia.

Mata pelajaran matematika di MA Negeri 1 Samarinda sesuai kurikulum 2013 revisi 2017 semester genap untuk kelas XI terdiri dari beberapa materi, salah satunya adalah materi barisan dan deret. Materi barisan dan deret merupakan bagian dari pokok bahasan aljabar yang sering muncul dalam tes (soal) ujian nasional. Oleh karena itu diperlukan pemahaman konsep yang baik untuk menyelesaikan dan memecahkannya. Sampai saat ini kemampuan siswa dalam memecahkan masalah pada materi barisan dan deret masih tergolong rendah. Hal ini sesuai dengan penjelasan Rahmawati (dalam Zulfikar et al., 2018) yang menyatakan bahwa, penguasaan siswa tentang materi barisan dan deret masih tergolong rendah jika dibandingkan dengan materi yang lain.

Berdasarkan hasil wawancara dengan guru matematika di kelas XI IPA MA Negeri 1 Samarinda, diperoleh informasi bahwa kemampuan siswa kelas XI IPA juga masih rendah. Dari penjelasan guru tersebut diperoleh keterangan bahwa, ketika siswa diberikan soal tentang barisan dan deret yang berbeda dengan contoh soal yang sudah dibahas di kelas, sebahagian besar dari jumlah siswa kesulitan memecahkan dan menyelesaikan permasalahan tersebut. Hal ini didukung oleh hasil observasi peneliti pada saat melaksanakan Praktik Lapangan Persekolahan (PLP) di MA Negeri 1 Samarinda.

Dalam Kamus Besar Bahasa Indonesia (2008), kemampuan berasal dari kata "mampu" yang memiliki kuasa (bisa, sanggup) melakukan sesuatu. Sedangkan kemampuan adalah kesanggupan, kecakapan, kekuatan, berusaha dengan diri sendiri.

Cahyani dan Setyawati (2017) menjelaskan bahwa kemampuan pemecahan masalah merupakan salah satu tujuan dalam proses pembelajaran ditinjau dari aspek kurikulum. Sedangkan kemampuan pemecahan masalah matematika adalah potensi atau keahlian siswa untuk memahami, menguasai, dan 
menyelesaikan soal pemecahan masalah matematika yang diberikan dengan cara berfikir yang lebih kompleks.

Sari (2019) mengemukakan bahwa, kemampuan pemecahan masalah yang dimiliki seseorang berbeda dengan kemampuan pemecahan masalah orang yang lain. Untuk membedakan kemampuan pemecahan masalah yang dimiliki siswa pada penelitian ini, peneliti menggunakan kemampuan pemecahan masalah berdasarkan taksonomi Strukture of Observed Learning Outcomes (SOLO). Alasan peneliti memilih taksonomi SOLO karena taksonomi SOLO memiliki karakter pemecahan masalah yang bersifat hirarkis sehingga dapat digunakan sebagai alat menentukan kualitas jawaban siswa terhadap suatu masalah matematika. Dengan menggunakan taksonomi SOLO dapat diukur pencapaian hasil belajar siswa, sehingga guru dapat mengetahui kemampuan dan kualitas respon siswa dalam memecahkan permasalahan matematika. Terdapat 5 level pada taksonomi SOLO yaitu prastruktural, unistruktural, multistruktural, relasional, dan abstak yang diperluas.

Kuswana (2012) menegaskan bahwa taksonomi SOLO memungkinkan untuk digunakan oleh para guru dalam mengidentifikasi kompleksitas dan kualitas pemikiran yang diharapkan dan dihasilkan oleh siswa. Hal ini, terutama yang diberlakukan sebagai aspek yang menantang seperti pemahaman konsep dan pemecahan masalah. Tujuan dari taksonomi SOLO adalah untuk menyediakan cara sistematis menggam-barkan bagaimana kinerja seorang siswa tumbuh dalam struktural kerumitan ketika menangani dan menyelesaikan permasa- lahan matematika. Adapun Indikator Kemampuan Pemecahan Masalah Matematika Berdasarkan Taksonomi SOLO Menurut Biggs dan Collis (dalam Herliani, n.d.).

Tabel 1. Indikator kemampuan pemecahan masalah berdasarkan taksonomi SOLO

\begin{tabular}{|c|c|}
\hline $\begin{array}{c}\text { Level } \\
\text { Taksonomi } \\
\text { SOLO }\end{array}$ & Indikator \\
\hline Prastrukural & $\begin{array}{l}\text { Siswa hanya memili- } \\
\text { ki sedikit informasi } \\
\text { bahkan sama sekali } \\
\text { tidak dapat meme- } \\
\text { cahkan masalah se- } \\
\text { hingga kesimpulan } \\
\text { tidak relevan atau ti- } \\
\text { dak tepat. }\end{array}$ \\
\hline Unistruktural & $\begin{array}{l}\text { Siswa mampu me- } \\
\text { mecahkan masalah } \\
\text { dengan mengguna- } \\
\text { kan satu penggal in- } \\
\text { formasi yang jelas } \\
\text { namun kesimpulan } \\
\text { masih sederhana. }\end{array}$ \\
\hline Multistruktural & $\begin{array}{l}\text { Siswa dapat menge- } \\
\text { lompokkan beberapa } \\
\text { informasi, memecah- } \\
\text { kan masalah dengan } \\
\text { beberapa strategi dan } \\
\text { melakukan perhitu- } \\
\text { ngan. }\end{array}$ \\
\hline Relasional & $\begin{array}{l}\text { Siswa dapat mema- } \\
\text { dukan penggalan } \\
\text { informasi yang terpi- } \\
\text { sah untuk memecah- } \\
\text { kan permasalahan, } \\
\text { membangun hubu- } \\
\text { ngan antar konsep } \\
\text { dan menguraikan in- } \\
\text { formasi menjadi satu } \\
\text { kesatuan yang koho- } \\
\text { ren sehingga dipero- } \\
\text { leh kesimpulan yang } \\
\text { benar. }\end{array}$ \\
\hline
\end{tabular}


Lanjutan Tabel 1. Indikator kemampuan pemecahan masalah berdasarkan taksonomi SOLO

\begin{tabular}{|c|l|}
\hline $\begin{array}{c}\text { Level } \\
\text { Taksonomi } \\
\text { SOLO }\end{array}$ & \multicolumn{1}{|c|}{ Indikator } \\
\hline & $\begin{array}{l}\text { Siswa dapat menje- } \\
\text { laskan hubungan be- } \\
\text { berapa konsep se- } \\
\text { hingga membentuk } \\
\text { gagasan baru, dapat }\end{array}$ \\
Abstrak yang & $\begin{array}{l}\text { menyusun suatu du- } \\
\text { gaan untuk membuat }\end{array}$ \\
& $\begin{array}{l}\text { suatu prinsip berupa } \\
\text { rumus, pola, atau } \\
\text { aturan untuk peme- } \\
\text { cahan permasalahan. }\end{array}$ \\
\hline
\end{tabular}

\section{METODE PENELITIAN}

Penelitian ini merupakan penelitian deskriptif dengan pendekatan kualitatif. Penelitian dilaksanakan pada bulan Januari - Februari 2020 di MA Negeri 1 Samarinda. Subjek penelitian adalah siswa kelas XI IPA sebanyak 66 siswa. Sedangkan objek penelitian adalah kemampuan siswa memecahkan permasalahan matematika pada materi barisan dan deret berdasarkan Taksonomi SOLO.

Instrumen yang digunakan pada penelitian ini adalah tes pemecahan masalah dan pedoman wawancara. Adapun teknik pengumpulan data yaitu pemberian tes secara tertulis, wawancara, dan dokumentasi. Sedangkan teknik analisis data adalah reduksi data, penyajian data, dan penarikan kesimpulan. Dalam mereduksi data, peneliti mengacu pada tujuan yang dicapai yaitu untuk mengetahui dan mengklasifikasikan kemampuan peme-cahan masalah siswa kelas XI IPA pada materi barisan dan deret berdasarkan Taksonomi SOLO. Untuk acuan dan ketentuan analisis data dalam penelitian ini peneliti mengikuti hal-hal sebagai berikut:

1. Siswa dikategorikan memiliki kemampuan pada tingkat prastruktural jika memenuhi indikator pada tingkat prastruktural yaitu hanya memiliki sedikit informasi bahkan sama sekali tidak dapat memecahkan permasalahan sehingga kesimpulan tidak tepat. Pada penelitian ini siswa dikategorikan memiliki kemampuan pada tingkat prastruktural jika tidak bisa menjawab dengan benar dari 5 soal yang diberikan.

2. Siswa dikategorikan memiliki kemampuan pada tingkat unistruktural jika memenuhi indikator pada tingkat unistruktural yaitu siswa dapat memecahkan masalah menggunakan informasi yang jelas dan langsung dapat digunakan untuk mencapai kesimpulan.

3. Siswa dikategorikan memiliki kemampuan pada tingkat multistruktural jika memenuhi indikator pada tingkat multistruktural yaitu siswa mampu mengelompokkan beberapa informasi yang jelas pada soal, memecahkan masalah dengan beberapa strategi dan melakukan perhitungan.

4. Siswa dikategorikan memiliki kemampuan pada tingkat relasional jika memenuhi indikator pada tingkat relasional yaitu siswa dapat memadukan informasi yang terpisah untuk memecahkan permasalahan, membangun hubungan antar konsep dan menguraikan informasi-informasi menjadi satu kesatuan yang koharen sehingga diperoleh solusi atau kesimpulan yang benar. 
5. Siswa dikategorikan memiliki kemampuan pada tingkat abstrak yang diperluas jika memenuhi indikator pada tingkat abstrak yang diperluas yaitu siswa dapat menjelaskan hubungan antar konsep sehingga membentuk suatu gagasan baru, dapat menyusun suatu dugaan untuk membuat suatu prinsip yang umum dan dapat membangun prinsip berupa rumus, pola, atau aturan untuk memecahakan permasalahan.

\section{HASIL PENELITIAN DAN PEMBA- HASAN}

Berdasarkan hasil penelitian di MA Negeri 1 Samarinda kelas XI IPA diperoleh skor dan tingkatan kemampuan siswa berdasarkan Taksonomi SOLO. Skor tertinggi yang diperoleh siswa adalah 79 dan skor terendah yang diperoleh siswa adalah 5. Adapun tingkatan kemampuan pemecahan masalah matematika siswa berdasarkan Taksonomi SOLO dapat dilihat pada Tabel 2.

Tabel 2. Frekuensi kemampuan pemecahan masalah matematika siswa kelas XI IPA berdasarkan taksonomi SOLO pada materi barisan dan deret di MAN 1 Samarinda tahun ajaran 2019/2020

\begin{tabular}{|c|c|}
\hline $\begin{array}{c}\text { Tingkatan Kemampuan } \\
\text { Taksonomi SOLO }\end{array}$ & Frekuensi \\
\hline Prastruktural & 5 \\
\hline Unistruktural & 15 \\
\hline Multistruktural & 29 \\
\hline Relasional & 14 \\
\hline $\begin{array}{c}\text { Abstrak Yang } \\
\text { Diperluas }\end{array}$ & 3 \\
\hline Jumlah & 66 \\
\hline
\end{tabular}

Berdasarkan Tabel 2 kemampuan pemecahan masalah matematika siswa kelas XI IPA berdasarkan Taksonomi SOLO pada materi barisan dan deret di MA Negeri 1 Samarinda tahun ajaran 2019/2020 diperoleh 5 siswa dengan kemampuan pada tingkat prastruktural, 15 siswa dengan kemampuan pada tingkat unistrutural, 29 siswa dengan kemampuan pada tingkat multistruktural, 14 siswa dengan kemampuan pada tingkat relasional dan 3 siswa dengan kemampuan abstrak yang di-perluas. Berdasarkan hasil analisis pada lembar jawaban 5 siswa yang dikategorikan pada tingkat prastruktural tidak dapat menyelesaikan permasalahan yang diberikan sesuai dengan indikator kemampuan pada tingkat prastruktural yaitu siswa dikategorikan pada tingkat prastruktural jika hanya memiliki sedikit informasi, tidak dapat memecahkan permasalahan yang diberikan sehingga kesimpulan tidak relevan dan tidak tepat. Terdapat 15 siswa yang dikategorikan memiliki kemampuan pada tingkat unistruktural karena memenuhi indikator kemampuan pemecahan masalah pada tingkat unistruktural yaitu siswa dapat memecahkan permasalahan menggunakan informasi yang jelas dan dapat langsung digunakan untuk memperoleh kesimpulan yang masih sangat sederhana. Terdapat 29 siswa dengan kemampuan pemecahan masalah pada tingkat multistruktural artinya siswa telah memenuhi indikator pada tingkat unistruktural dan memenuhi indikator pada tingkat multistruktural yaitu dapat mengelompokkan dua atau lebih informasi yang terdapat pada soal, memecahkan masalah dengan beberapa strategi dan melakukan perhitungan. 
Terdapat 14 siswa dengan kemampuan pada tingkat relasional, artinya siswa telah memenuhi indikator pada tingkat unistruktural dan multistruktural, serta memenuhi indikator pada tingkat relasional yaitu siswa dapat memadukan informasi yang terpisah untuk memecahkan permasalahan, membangun hubungan antar konsep dan menguraikan informasi-informasi menjadi satu kesatuan yang koharen sehingga diperoleh solusi atau kesimpulan yang benar. Dan terdapat 3 siswa dengan kemampuan abstrak yang diperluas artinya siswa telah memenuhi indikator pada tingkat unistruktural, multistruktural dan relasional, serta memenuhi indikator pada tingkat abstrak yang diperluas yaitu siswa dapat menjelaskan hubungan antar konsep sehingga membentuk suatu gagasan baru, dapat menyusun suatu dugaan untuk membuat suatu prinsip yang umum dan dapat membangun prinsip berupa rumus, pola, atau aturan untuk memecahakan permasalahan. Berikut contoh permasalahan matematika materi barisan dan deret. Perhatikan Gambar 1.

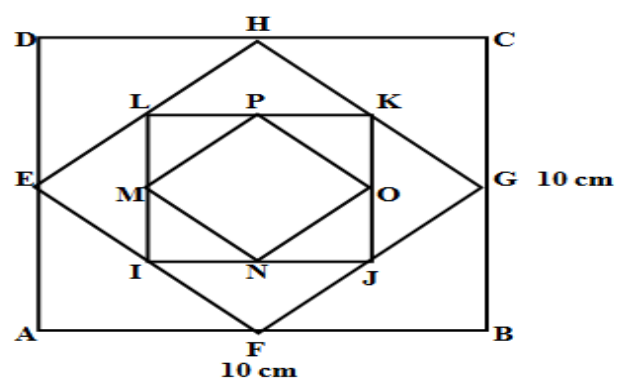

Gambar 1. Persegi

Sebuah persegi ABCD mempunyai panjang sisi $10 \mathrm{~cm}$. Di dalamnya dibuat persegi EFGH dengan titik sudutnya berada di tengah-tengah sisi-sisi ABCD. Di dalam persegi EFGH dibuat lagi persegi IJKL yang titik sudutnya berada di tengah-tengah sisi-sisi EFGH, dan seterusnya sampai banyak persegi tak hingga. Tentukanlah jumlah luas persegi yang mungkin terbentuk!

\section{Kemampuan Pemecahan Masalah Pada Tingkat Prastruktural.}

Siswa yang berada pada tingkat kemampuan prastruktural artinya siswa tidak mampu mengerjakan permasalahan yang diberikan, hanya memiliki sedikit informasi, tidak dapat memecahkan permasalahan yang diberikan, sehingga kesimpulan tidak relevan atau tidak tepat. Berikut ini contoh pekerjaan siswa yang berada pada tingkat prastruktural.

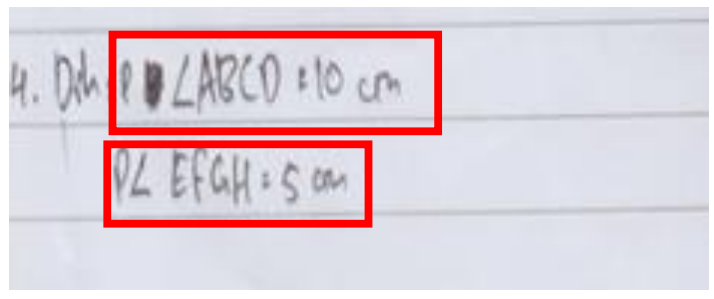

Gambar 2. Kemampuan tingkat prastruktural

Berdasarkan Gambar 2, siswa yang berada pada tingkat prastruktural hanya memiliki sedikit informasi bahkan sama sekali tidak memahami permasalahan. Siswa hanya mampu menuliskan panjang sisi persegi ABCD dan Panjang persegi EFGH. Siswa salah dalam menyimbolkan panjang sisi pada persegi.

\section{Kemampuan Pemecahan Masalah}

\section{Pada Tingkat Unistruktural}

Siswa dikatakan berada pada tingkat unistruktural jika memenuhi indikator kemampuan pemecahan masalah pada tingkat unistruktural yaitu mampu memecahkan permasalahan dengan menggunakan sepenggal informasi yang jelas sehingga bisa langsung dapat 
digunakan untuk menyelesaikan permasalahan dan memberikan kesimpulan yang masih sangat sederhana.

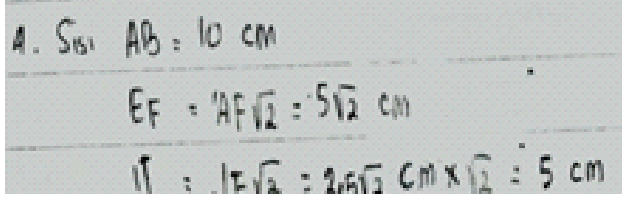

Gambar 3. Kemampuan tingkat unistruktural

Pada permasalahan ini siswa dikatakan berada pada tingkat unistruktural jika dapat menentukan panjang sisi persegi yang lain menggunakan informasi yang tersedia pada soal yaitu menggunakan panjang sisi persegi $\mathrm{ABCD}$ dan untuk panjang sisi yang lain dapat dicari menggunakan rumus diagonal sisi persegi.

\section{Kemampuan Pemecahan Masalah Pada Tingkat Multistruktural}

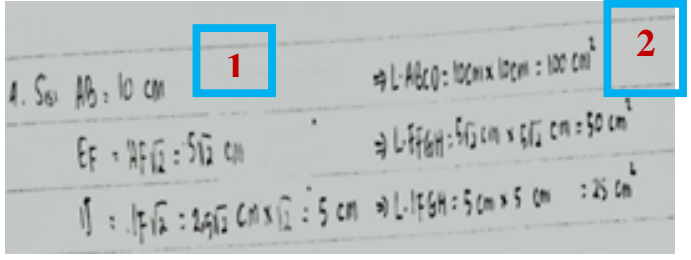

Gambar 4. Kemampuan tingkat multistruktural

Siswa dikatakan berada pada tingkat multistruktural jika memenuhi indikator pada kemampuan pemecahan masalah pada tingkat unistruktural dan multistruktural. Indikator pada tingkat multistruktural yaitu mampu mengelompokkan beberapa informasi yang tersedia pada soal pada permasalahan di ini siswa mampu mengelompokkan informasi panjang sisi persegi yang lain dan dapat menggunakan rumus diagonal sisi persegi. Siswa mampu memecahkan permasalahan menggunakan beberapa strategi dan dapat melakukan perhitungan dengan benar pada permasalahan ini siswa menggunakan dua strategi yaitu menentukan panjang sisi persegi yang lain dan dapat menentukan luas persegi menggunakan informasi yang diperoleh.

\section{Kemampuan Pemecahan Masalah Pada Tingkat Relasional}

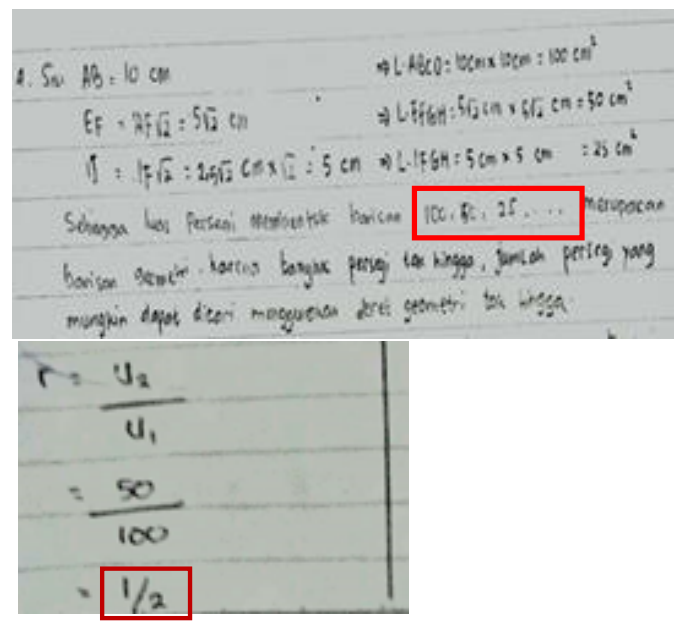

Gambar 5. Kemampuan tingkat relasional

Siswa dikatakan memiliki kemampuan pada tingkat relasional jika memenuhi indikator kemampuan pemecahan masalah pada tingkat unistruktural, multistruktural dan relasional. Adapun indikator kemampuan pemecahan masalah pada tingkat relasional yaitu siswa dapat memadukan informasi yang terpisah untuk memecahkan permasalahan. Pada permasalahan ini siswa memperoleh informasi panjang sisi persegi yang lain dan luas persegi, siswa harus dapat menghubungkan informasi yang diperoleh dengan materi barisan dan deret. Siswa dapat membangun hubungan antar konsep dan menguraikan informasi-informasi 
yang diperoleh menjadi satu kesatuan yang koharen sehingga diperoleh solusi atau kesimpulan yang benar. Berdasarkan gambar 5 pada permasalahan ini siswa harus dapat menghubungkan bahwa luasluas persegi yang diperoleh membentuk suatu barisan geometri dengan rasio $\frac{1}{2}$.

\section{Kemampuan Pemecahan Masalah Pada Tingkat Abstrak yang Diper- luas}

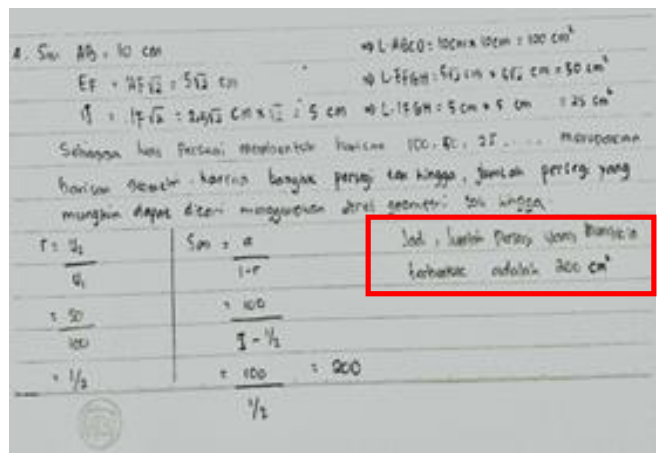

Gambar 5. Kemampuan tingkat relasional

Siswa dikatakan memiliki kemampuan pemecahan masalah pada tingkat abstrak yang diperluas jika memenuhi indikator kemampuan masalah pada tingkat unistruktural, multistruktural, relasional dan abstrak yang diperluas. Adapun indikator pada tingkat abstrak yang diperluas yaitu dapat menjelaskan hubungan antar konsep sehingga diperoleh suatu gagasan baru, siswa dapat menyusun dugaan untuk suatu prinsip yang umum dan dapat membangun prinsip berupa rumus, pola, atau aturan untuk memecahkan permasalahan matematika. Pada permasalahan ini berdasarkan gambar 6 siswa dapat menghubungkan konsep barisan geometri yang diperoleh dengan konsep deret geometri tak hingga, siswa dapat menjelaskan bahwa karena pada soal yang ditanya jumlah luas persegi yang mungkin dan banyak persegi tak hingga maka dapat diselesaikan menggunakan rumus deret geometri tak hingga.

\section{KESIMPULAN}

Berdasarkan hasil analisis dan pembahasan tentang kemampuan pemecahan masalah matematika materi barisan dan deret kelas XI IPA di MA Negeri 1 Samarinda berdasarkan Taksonomi SOLO diperoleh kesimpulan sebagai berikut:

1. Siswa dengan kemampuan pemecahan masalah pada tingkat prastruktural ada sebanyak 5 siswa. Siswa pada tingkat prastruktural hanya memiliki sedikit informasi bahkan sama sekali tidak dapat memecahkan masalah sehingga kesimpulan tidak relevan atau tidak tepat.

2. Siswa dengan kemampuan pemecahan masalah pada tingkat unistruktural ada sebanyak 15 siswa. Siswa yang memiliki kemampuan pemecahan masalah pada tingkat unistruktural memenuhi indikator kemampuan pemecahan masalah pada tingkat unistruktural.

3. Siswa dengan kemampuan pemecahan masalah pada tingkat multistruktural ada sebanyak 29 siswa. Siswa memenuhi indikator kemampuan pemecahan masalah pada tingkat unistruktural dan multistruktural

4. Siswa dengan kemampuan pemecahan masalah pada tingkat relasional ada sebanyak 14 siswa. Siswa yang memiliki kemampuan pemecahan masalah pada tingkat relasional memenuhi indikator kemampuan pemecahan 
masalah pada tingkat unistruktural, multistruktural, dan relasional.

5. Siswa dengan kemampuan pemecahan masalah pada tingkat abstrak yang diperluas ada sebanyak 3 siswa. Siswa yang memiliki kemampuan pemecahan masalah pada tingkat abstrak memenuhi indikator kemampuan pemecahan masalah pada tingkat unistruktural, multistruktural, relasional, dan abstrak yang diperluas.

Sehingga sebagian besar kemampuan pemecahan masalah matematika siswa kelas XI IPA pada materi barisan dan deret berdasarkan taksonomi SOLO masih pada tingkat multistruktural karena hanya memenuhi indikator pada tingkatan unistruktural dan tingkat multistruktural.

\section{DAFTAR PUSTAKA}

Cahyani, H., \& Setyawati, R. W. (2017). Pentingnya peningkatan kemampuan pemecahan masalah melalui PBL untuk mempersiapkan generasi unggul menghadapi MEA. PRISMA, Prosiding Seminar Nasional Matematika, 151-160.

Herliani, H. (n.d.). Penggunaan Taksonomi SOLO (Structure of Observed Learning Outcomes) pada Pembelajaran Kooperatif Truth and Dare dengan Quick on the Draw untuk Meningkatkan Keterampilan Berpikir Siswa pada Biologi SMA. Proceeding Biology Education Conference: Biology, Science, Enviromental, and Learning, 13(1), 232-236.

Kuswana, W. S. (2012). Taksonomi kognitif. Bandung: PT Remaja Rosdakarya.

Nasional, D. P. (2008). Kamus besar bahasa Indonesia pusat bahasa.
Jakarta: PT Gramedia Pustaka Utama.

Sari, S. A. L., Sutriyono, S., \& Pratama, F. W. (2019). Analisis Kemampuan Pemecahan Masalah Matematika dengan Taksonomi SOLO pada Siswa SMA. JUMLAHKU: Jurnal Matematika Ilmiah STKIP Muhammadiyah Kuningan, 5(1), 114.

Zulfikar, M., Achmad, N., \& Fitriani, N. (2018). Analisis Kemampuan Penalaran Matematik Siswa SMP di Kabupaten Bandung Barat Pada Materi Barisan dan Deret. Jurnal Pendidikan Tambusai, 2(3), 18021810. 
| Jurnal PRIMATIKA, Volume 9, Nomor 1, Juni 2020

10 Analisis Kemampuan Pemecahan Masalah Matematika Berdasarkan Taksonomi SOLO Halimah - Zainuddin Untu - Suriaty 